\title{
Хірургічне лікування верхніх низхідних гнійних медіастинітів
}

\begin{abstract}
Мета роботи: покращити результати лікування хворих на низхідний гнійний медіастиніт (НГМ) шляхом удосконалення хірургічних доступів до середостіння, методів місцевого хірургічного лікування.

Матеріали і методи. Проведено обстеження та лікування 170 хворих із низькими флегмонами шиї (ФШ), які перебували на лікуванні у відділені торакальної хірургії Івано-Франківської обласної клінічної лікарні з 2000 до 2018 р. Серед хворих у 53 (31,2\%) хворих ФШ ускладнилася розвитком НГМ. Серед 53 хворих чоловіків було 34 (64,2 \%), жінок - 19 (35,8 \%), віком від 21 до 72 років, у середньому вік хворих становив $(41,3 \pm 3,9)$ року.

Результати досліджень та ї обговорення. Хірургічне лікування НГМ передбачає усунення первинного джерела захворювання, вибір операційного доступу до середостіння, розкриття всіх гнійних ділянок та їх санацію, забезпечення постійного видалення гнійних мас із клітковини середостіння. Для попередження поширення ФШ у клітковину середостіння ми застосовували оригінальну методику інтрамедіастинального введення антибактеріальних середників (IMBA). При застосуванні IMBA нам вдалося знизити частоту розвитку НГМ із 50,7 до 9,1 \% випадків. У 10 (20,8 \%) хворих ми провели додаткове розкриття медіастинальної плеври верхнього середостіння за допомогою відеоасистованої торакоскопії (ВАТС). Використання ВАТС в хірургічному лікуванні НГМ дозволяє провести повноцінний огляд медіастинальної плеври та середостіння, дозволяє ефективно розкрити та санувати всі уражені ділянки середостіння та провести їх адекватне дренування. При застосуванні хірургічніх втручань на випередження поширення гнійного процесу у середостінні нам вдалося знизити кількість повторних оперативних втручань із 45,3 до 3,7 \%.
\end{abstract}

Ключові слова: медіастиніт; низхідний гнійний медіастиніт; хірургічне лікування гнійного медіастиніту.

Постановка проблеми та аналіз останніх досліджень та публікацій. Лікування хворих із низхідним гнійним медіастинітом (НГМ) є однією із найбільш складних проблем сучасної хірургії. Летальність у хворих із НГМ може сягати 1780 \% [1]. За даними ряду авторів, у хворих на НГМ сепсис діагностують у 45-100 \% випадків [1, 2]. Основною причиною розвитку НГМ є поширення флегмон шиї (ФШ) у середостіння, тому одним із важливих факторів є радикальне хірургічне лікування, яке б в першу чергу забезпечувало усунення причини ФШ та НГМ. Визначення хірургічної тактики і операційного доступу для забезпечення адекватної санації гнійної клітковини та дренування $є$ вирішальним фактором в успішному лікуванні хворих. Деякі автори вказують, що цервікотомічний доступ є цілком достатній [3], інші вважають, що оптимальним доступом є двобічна цервікотомія із черезшийною медіастинотомією при всіх видах НГМ [4]. Вирішальне значенню для хірургічної тактики лікування НГМ відіграє вибір операційного доступу до середостіння, який би передбачав повну візуалізацію уражених ділянок середостіння із можливістю повноцінного розкриття гнійників та їх санації. В літературі описано багато як плевральних, так і екстраплевральних хірургічних доступів [2, 5, 6]. Питання ефективності кожного з них надзвичайно дискусійні серед авторів. Так, при верхніх НГМ рекомендують проводити через шийну медіастинотомію за
B. I. Разумовським. Інші вказують на ефективність повздовжньої стернотомії та парастернального доступу при передніх НГМ за Маделунгом $[1,4]$. Головним їх недоліком $€$ можливість розвитку остеомієліту груднини. Деякі авторів вказують на необхідність проведення саме екстраплевральних доступів, які б попереджали потрапляння інфекції у плевральну порожнину і розвиток емпієми плеври $[7,8]$. Проте багато авторів вказує на недостатню ефективність екстраплевральних доступів, їх погану візуалізацію, не радикальність розкриття віх гнійних ділянок середостіння [9]. За останні роки все частіше з'являються публікації про застосування ВАТС у лікуванні хворих iз НГМ $[10,11]$.

Мета роботи: покращити результати лікування хворих на низхідний гнійний медіастиніт шляхом удосконалення хірургічних доступів до середостіння, методів місцевого хірургічного лікування.

Матеріали і методи. Проведено обстеження та лікування 170 хворих із низькими ФШ, які знаходилися на лікуванні у відділені торакальної хірургії Івано-Франківської обласної клінічної лікарні з 2000 по 2018 рр. Серед цих хворих у 97 (57,1\%) із 170 гнійно-некротичне запалення обмежилося клітковинними міжфасціальними проміжками на шиї без проникнення гнійної інфекції у середостіння. ФШ ускладнилася розвитком НГМ у 73 (42,9 \%) хворих. За поширеністю гній- 
ного процесу розрізняли передньо-верхній медіастиніт (ПВМ) при локалізації гнійників у передньоверхньому середостінні - 29 (26,7 \%) хворих, верхній медіастиніт (BM) - 24 (21,8 \%), при поширенні на все верхнє середостіння до рівня дуги аорти та біфуркації трахеї або до рівня 4-го грудного хребця, задній медіастиніт - 28 (25,4%), при поширені у заднє середостіння нижче біфуркації трахеї та тотальний медіастиніт - 29 (26,7%) хворих при гнійному ураженні всіх відділів середостіння.

Саме 53 (72,6 \%) хворих із ПВМ та ВМ були предметом нашого дослідження. Серед 53 хворих чоловіків було 34 (64,2 \%), жінок - 19 (35,8 \%), віком від 21 до 72 років, у середньому вік хворих становив $(41,3 \pm 3,9)$ року.

Результати досліджень та їх обговорення. Хірургічне лікування НГМ прямо залежить від його виду, поширення гнійного процесу в середостінні та наявності ускладнень.

Хірургічне лікування НГМ передбачає:

1. Усунення первинного джерела захворювання.

2. Вибір операційного доступу до середостіння.

3. Розкриття всіх гнійних ділянок середостіння.

4. Санацію уражених ділянок.

5. Забезпечення постійного видалення гнійних мас із клітковини середостіння та інших порожнин грудної порожнини.

Одним із перших етапів хірургічного лікування верхніх низхідних гнійних медіастинітів (ВНГМ) є усунення джерела первинного захворювання. Це забезпечується розкриттям і дренуванням гнійників шиї та обличчя, що були безпосередньою причиною ВНГМ. Лікування тонзилогенних ФШ і НГМ слід розпочинати із розкриття паратонзилярних абсцесів. Лікування одонтогенних ГГМ слід розпочинати із санації ротової порожнини, екстирпації зуба, який є причиною гнійного процесу. Ряд хворих були переведені із інших відділень в зв’язку з тим, що на первинних етапах їм було надано неадекватну хірургічну допомогу. Так, 18 (33,9 \%) хворих були переведені із спеціалізованих відділень, а саме 14 (26,4%) із відділень щелепно-лицевої хірургії та 4 (7,5%) із ЛОР відділень. При цьому у всіх хворих були типові недоліки хірургічних тактик, а саме недостатня довжина хірургічних доступів, неадекватна санація і дренування гнійних вогнищ, невчасна діагностика поширення гнійного процесу на шию та середостіння.

Ми проаналізували результати лікування наших хворих і визначилися із тактикою лікування різних форм ВНГМ. При діагностованій глибокій ФШ, ускладненій ВНГМ, всі хворі були проопе- ровані. Хірургічне лікування розпочинали з розкриття глибокої ФШ та дренування іï міжфасціальних проміжків. Враховуючи дані літератури про ефективність різних хірургічних доступів при лікуванні ФШ ми застосовували передньо-бокову цервікотомію за І. Разумовським, яку було застосованоу у 52 (98,1 \%) хворих.

Розкриття глибоких міжфасціальних проміжків шиї проводили пошарово, згідно з анатомічними орієнтирами, що передбачає адекватну, широку експлорацію тканин, ретельну ревізію зони ураження (з урахуванням сусідніх анатомічних футлярів), контроль шляхів можливого поширення інфекції, елімінацію гною, максимальне видалення очевидних і неочевидних некрозів. Для забезпечення повноцінного дренування “по прямій лінії” накладали контрапертури, застосовували товсті дренажні поліхлорвінілові трубки до 1 см в діаметрі, тонкі мікроіригатори та гумові смужки. Розміщення дренажів згідно з напрямками ранового каналу показано на рисунку 1.

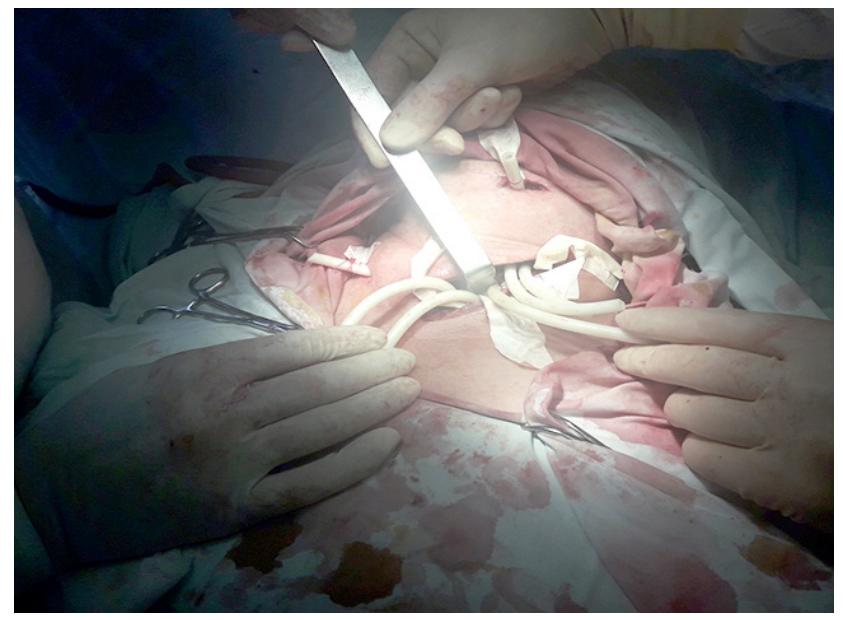

Рис. 1. Фото. Хворий П., 61 рік, медична карта стаціонарного хворого № 1090616. Діагноз: гостра флегмона підщелепової, підборідної ділянок та шиї зліва. Розміщення дренажів та контрапертур дренажів згідно з напрямками поширення гною.

Враховуючи високу ймовірність поширення низьких ФШ у клітковину середостіння із розвитком ВНГМ, ми застосували оригінальну методику інтрамедіастинального введення антибактеріальних середників (IMBA) для попередження поширення ФШ у клітковину середостіння (патент України № 128808). Метою даної методики було створення нульового або позитивного внутрішньогрудного тиску для усунення присмоктувальної дії середостіння, що попереджує поширення гнійної інфекції із міжфасціальних проміжків шиї у клітковину середостіння. Другим важливим 
чинником IMBA $є$ створення антибактеріального бар’єра між гнійною ділянкою шиї і середостіння з метою попередження потрапляння гнійної інфекції у клітковину середостіння. Для IMBA застосовували антибактеріальні середники та антисептики, які запобігали поширенню інфекції, створювали місцеву антибактеріальну дію та відмежовували здорове середостіння від гнійної порожнини. Суть методики полягає у наступному: після завершення розкриття флегмони шиї в проекції яремної вирізки груднини чітко по серединній лінії за методикою В. Казанцева проводили введення мікрокатетера за методом Сельдінгера у клітковину середостіння на глибину до $1-2$ см нижче від задньої пластини груднини до середини рукоятки груднини.

Після введення катетера інтрамедіастинально краплинним методом вводимо розчин антибіотиків із розрахунку 1,0 г антибіотика в 100-150 мл ізотонічного фізіологічного розчину протягом 2-3 годин. Даний об'єм розчину дозволяє вирівняти негативний внутрішньогрудний тиск у середостінні й усунути присмоктувальну дію середостіння. Враховуючи відсутність у середостінні будьяких фасціальних перепон, інфузія протягом цього часу забезпечує розповсюдження антибіотику по всій клітковині середостіння, що створює виражений місцевий антибактеріальний ефект. Таке введення розчинів із антибіотиком проводили 23 рази на добу чергуючи введення антибіотиків та антисептиків. Із антибактеріальних препаратів найчастіше застосовували розчини цефалоспоринів 3- 4 покоління із розрахунку 1,0 г на одне введення. Із антисептиків застосовували декасан.

IMBA проводилося у хворих, у яких проведено розкриття низької ФШ на рівні яремної вирізки. Даний метод було використано у 33 (19,4 \%) хворих. При цьому при застосуванні IMBA у 30 (90,9 \%) хворих гнійний процес було ліквідовано на стадії ФШ без поширення гнійного процесу в клітковину середостіння. Розвиток НГМ спостерігали лише у 3 (9,1\%) хворих при низьких ФШ, у хворих із надмірною масою, при пізній госпіталізації (більше 3-х днів від початку захворювання) та вираженою супутньою патологією (цукровий діабет 2 типу, ішемічна хвороба сереця). У групі порівняння (137 хворих), у яких даний метод не був застосований, ФШ ускладнилася НГМ у 70 (50,7 \%) хворих.

При ФШ та розвитку ВМ основним хірургічним доступом було цервікотомія на стороні ураження з розкритям гнійників у клітковині середостіння. Через шийне дренування середостіння можливе, якщо по даних спіральної компютер- ної томографії (СКТ) гнійний процес не поширився нижче біфуркації трахеї, що відповідає рівню Th4 - Th5. Розкриття і дренування гнійників при ВМ тільки через шийний доступ провели у 30 (56,6 \%) із 53 хворих. При цьому проводили розкриття тупим шляхом клітковини середостіння за ходом гнійних каналів із видалення гною та некротичних тканин під контролем зору. Операцію завершували дренуванням середостіння товстими (до 1,1 см) дренажами із перфорованими отворами і під'єднували до активної аспіраційної системи. Вибір кількості, розміщення і довжини дренажів визначається безпосередньо під час операції. Дистальний кінець дренажів проводили до дна рани, проте він має вільно бути розміщений у нижньому полюсі гнійної порожнини. Кількість дренажів визначається за кількостю ранових каналів із врахуванням шляхів поширення гнійної інфекції на шиї та середостінні. Для проточного промивання в ранові канали вводили тонкі катетери для постійного промивання гнійних порожнин. Катетери під’єднували до краплинної системи, через яку вводити розчини антисептиків (декасан, хлоргексидин). Кількість антисептичних розчинів становили до $1-2$ літри на добу. При цьому доставку антисептиків проводили через іригаційні катетери, а відтік відбувався через дренажні трубки.

Використання черезшийних доступів при ВМ не завжди ефективно, оскільки недостатня зона операційного втручання при використанні класичних інструментів і відсутній візуальний контроль за хірургічними маніпуляціями. Це пов’язано із великою глибиною ранового каналу із шийного доступу, вузький простір для маніпуляцій і анатомічно небезпечне розміщення великих артеріальних стовбурів та вен у верхньому середостінні. В зв'язку з цим у 24 (45,3 \%) ми змушені були провести повторні операційні втручання (ПОВ) внаслідок недостатньо ефектиного розкриття гнійників через шийний доступ та при поширенні гнійно-запального процесу нижче біфуркації трахеї. Серед ПОВ основними методами були торакотомія на сторонні ураження - у 18 (75 \%) із 24 хворих, відео-асистована торакоскопія (ВАТС) із додатковою медіастинотомією та дренуванням середостіння та плевральної порожнини - у 5 (20,8 \%), двобічна торакотомія - у одного (4,2 \%) хворого.

Наводимо власне спостереження.

Хворий Г., 41 р. медична карта стаціонарного хворого № 2129216, госпіталізований у відділення торакальної хірургії обласної клінічної лікарні 21.11.16 р. із діагнозом: гостра глибока флегмона шиї. Гострий передньо-верхній медіастиніт, сепсис. 21.11.2016 р. провели двобічну цервікото- 
мію, некректомію та дренування шиї та передньоверхнього середостіння. Після хірургічного лікування хворий був переведений й відділення реанімації. Вранці 22.11.16 р. стан хворого був важкий, хворий перебував на штучній вентиляції легень, гемодинаміка не стабільна із вазопресорною підтримкою. У загальному аналізі крові наростання лейкоцитозу до 11,8 х 109 в 1 л та кількості паличкоядерних нейтрофільних гранулоцитів до 23. При проведення УЗД - наявність рідини до 6 см в лівій та 8 см у правій плевральних порожнинах, при ехокардіоскопії - наявність сепарації листків перикарду до 1,9 см. При проведені рентгенографії ОГК виявлено - в проекції дуги аорти гомогенне затемненя з нечіткими відносно рівними контурами, ознаки двобічного гідротораксу. Враховуючи наростання ознак гнійної інтоксикації та появу рідини в обох плевральних порожнинах та перикарді, хворому 22.11.16 р. проведено операцію правобічну бокову торакотомію. При цьому в правій плевральній порожнині виявлено до 400 мл рідкого смердючого гною. В проекції переднього середостіння виявлено гнійно-некротичні зміни медіастинальної плеври, проведено розкриття всіх уражених ділянок медіастинальної плеври. Проведено фенестрацію перикарду - виділилося до 150 мл мутного гнійного ексудату. Дреновано 3- ма дренажами. Хворого для подальшого лікування було переведено у відділення реанімації. Вранці 23.11.06 р. стан хворого був важкий. Рівень лейкоцитозу зберігається на рівні 11,7 х 109, кількість паличкоядерних нейтрофільних гранулоцитів зросла до 29. При рентгенографії ОГК виявлено розширення тіні середостіння в ліву сторону, за даними УЗД - кількість рідини у лівому плевральному синусі зросла до 11 см. Враховуючи негативну динаміку стану хворого та показників гнійної інтоксикації 23.11.06 хворому проведено лівобічну торакотомію. У плевральній порожнині виявлено до 800 мл мутного гнійного ексудату, медіастинальна плевра з ділянками некрозу сірого кольору, в аортальному вікні виявлено гнійник, який розкрито, виділилося до 80 мл смердючого гною. Між низхідною аортою та стравоходом в нижньому середостінні додатково розкрито гнійник - виділилося до 40 мл гною. Середостіння і плевральну порожнину промито розчинами антисептиків, дреновано 3-ма дренажами. 24.11.06 стан хворого дещо покращився, дихання на штучній вентиляції легень, гемодинаміка не стабільна, проте кількість вазопресорів мінімальна. Кількість лейкоцитів у периферійній крові знизилася до 8,9 х $10^{9}$ та кількості паличкоядерних нейтрофільних гранулоцитів до 13. В наступні дні стан хворого поступово покращився. 27.11.16 хворий був на самостійному диханні, 29.11. переведений із відділення реанімації у торакальну хірургію. Хворому проводилися активні санації гнійних ран шиї, середостіння та плевральних порожнини з промиванням тричі на добу. На 35 добу від часу госпіталізації хворого виписали в задовільному стані.

Аналізуючи приведене спостереження, можна зробити висновки, що оперативна тактика з першої доби була невірна і не в повному об’ємі. Враховуючи гнійно- некротичні зміни клітковини шиї та поширення гнійного процесу за типом некротизуючого фасціїту у передньо-верхнє середостіння вже в першу добу необхідно було проводити додаткові хірургічні втручання на випередження гнійного процесу. Другою помилкою ми вважаємо, що навіть на другу добу хворому не було проведено хірургічне втручання з протилежної сторони. При однобічній торакотомії не були розкриті гнійники лівої частини середостіння, технічно виявити які з правої сторони досить складно. Все це призвело до поширення гнійної інфекції на всі відділи середостіння з розвитком тотального НГМ та тяжкого сепсису.

Враховуючи негативний досвід із врахуванням високої частоти ПОВ у хворих із ВМ, ми вважаємо, що більш ефективно проводити додаткові хірургічні втручання, які спрямовані на випередження поширення гнійного процесу. В зв’ язку з цим, у 18 (33,9 \%) хворих із ВМ при сумнівах у поширеності гнійного процесу та достатній ефективності черезшийного дренування ми провели одномоментно із цервікотомією додаткові операційні втручання. Так, у 8 (16,6 \%) із ВМ було проведено торакотомію на стороні ураження з додатковим розкриттям медіастинальної плеври. В усіх випадках додатковим критерієм до показань для проведення торакотомії було наявність рідини у плевральній порожнині за даними рентгенографії ОГК та УЗД плевральних синусів. У 10 (20,8 \%) хворих ми провели додаткове розкриття медіастинальної плеври верхнього середостіння за допомогою ВАТС.

Показаннями до проведення ВАТС як додаткового методу операційного втручання при ВМ ми вважаємо:

1. Недостатньо ефективне розкриття клітковини середостіння черезшийним доступом.

2. Сумніви у поширенні процесу нижче біфуркації трахеї.

3. Наявність ексудативного плевриту чи емпієми плеври.

4. Порушення цілісності медіастинальної плеври при проведенні черезшийного розкриття середостіння. 
5. Поширення гнійного процесу в заднє середостіння.

Недостатньо ефективне розкриття клітковини середостіння черезшийним доступом можливе у хворих із надлишковою масою, при недостатньому досвіді оперуючого хірурга, при наявності і навіть при підозрі на поширення гнійної інфекції за типом некротизуючого фасціїту.

При порушенні цілісності медіастинальної плеври при проведенні черезшийного розкриття середостіння виникає потрапляння інфекції у плевральну порожнину. Тому ВАТС необхідно проводити для діагностики пошкодження, проведення додаткової медіастинотомії (при потребі) та запезпечення дренування середостіння в місці перфорації із метою запобігання поширенню інфекції та видалення ексудату із плевральної порожнини.

Таким чином, ПОВ в групі, де використовували лише черезшийне дренування гнійників середостіння, було застосовано у 24 (45,3 \%) хворих. При застосуванні ВАТС одномоментно разом із черезшийним дренуванням нам вдалося знизити кількість ПОВ із 45,3 \% до 3,7 \%. Лише у 2 (3,7 \%) хворих ми змушені були застосувати ПОВ, а саме торакотомію на стороні ураження при поширенні гнійно-запального процесу в нижні відділи середостінння із розвитком тотального НГМ у одного хворого та провести додаткову ВАТС із протилежної сторони при появі на 4-ту добу від моменту першої операції гнійного ексудату в протилежній плевральній порожнині.

3 метою покращення діагностики поширення гнійної інфекції у середостіння ми при черезшийній санації проводили промивання гнійних порожнин із використанням тугого наповнення розчином бриліантового зеленого. При цьому при проведені ВАТС спостерігали ділянки поширення бриліантового зеленого у клітковині середостіння, які не завжди можна було визначити без застосування фарбника. Це також давало змогу хірургічно рокрити всі гнійні канали за ходом поширення фарбника, які в звичайних умовах не завжди вдавалося виявити. Мета ВАТС - це діагностика стану медіастинальної плеври та клітковини середостіння, медіастинотомія та забезпечення дренування середостіння та плевральної порожнини. Операцію проводили у положенні хворого на боці протилежному до сторони ураження. Сторону ураження визначали за даними СКТ, локалізації гнійного процесу на шиї (справа чи зліва) та наявності випоту чи гною у плевральній порожнини. При цьому при появі гнійного ексудату навіть на стороні, протилежній до ФШ, ВАТС проводили на стороні наявного гідротораксу. Після введення торакоскопічних портів ретрактором легені звільняли доступ до медіастинальної плеври верхнього середостіння, виявляли ділянки запальної інфільтрації клітковини середостіння, некротичні ділянки або місця, які забарвлювалися фарбником. Після цього проводили розсічення медіастинальної плеври до ділянок здорових тканин. Проводили видалення некротизованих ділянок середостіння, інфільтровані частини тупо препарували для створення умов для відтоку гною та запального ексудату. При цьому виникало питання про доцільність з’єднання гнійних каналів, проведених із черезшийного та трасплеврального доступів. У 4 (7,5 \%) ми з’єднали гнійні канали, проте в післяопераційний період спостерігали відсутність герметизму плевральної порожнини від 4 до 12 днів у всіх хворих за рахунок потрапляння повітря через шийний доступ. Це призводило до колапсу легені та розвитку поширеної емпієми плеври у 2-х хворих. Крім цього, відсутність герметизму плевральної порожнини не дозволяла нам проводити активне дренування гнійного вмісту. Тому ми були змушені проводити штучне роз’єднання ранових каналів у 2-х хворих шляхом тугого тампонування дна рани через шийний доступ для створення умов для герметизму плевральної порожнини і розправлення легені. Операцію завершували дренуванням середостіння та плевральної порожнини.

Таким чином, при ВМ ми використовували хірургічні втручання на випередження поширення гнійного процесу у середостінні, а саме цервікотомію та ВАТС, які проведено у 10 (18,8\%) хворих, при цьому нам суттєво вдалося знизити кількість ПОВ саме за рахунок розширення показань до проведення малоінвазивних втручань при ВМ із 45,3 до $3,7 \%$.

Висновки. 1. Хірургічне лікування низхідного гнійного медіастиніту першочергово передбачає усунення первинного гнійного вогнища на шиї.

2. Використання інтрамедіастинального введення антибактеріальних середників дозволяє попередити поширення гнійної інфекції із міжфасціальних проміжків шиї у середостіння та знизити частоту розвитку низхідного гнійного медіастиніту із 50,7 до 9,1 \% випадків.

3. При застосуванні хірургічних втручань на випередження поширення гнійного процесу у середостінні нам вдалося знизити кількість повторних операційних втручань із 45,3 до 3,7 \%.

4. Використання відеоасистованої торакоскопії в хірургічному лікуванні низхідних гнійних медіастинітів дозволяє провести повноцінний огляд медіастинальної плеври та дозволяє ефективно розкрити та санувати всі уражені ділянки середостіння та провести їх адекватне дренування. 


\section{СПИСОК ЛІТЕРАТУРИ}

1. Абакумов М. М. Двадцатилетний опыт диагностики и лечения при различных формах гнойного медиастинита / М. М. Абакумов, А. Н. Погодина, Т. Г. Бармина // Вестник хирургии. -2001. - №1. - С. 80-85.

2. Шипулин П. П. Лечение острого гнойного медиастинита /

П. П. Шипулин // Хирургия. - 2001. - № 8. - С. 58-61.

3. Hofmann H. S. Mediastinitis / H. S. Hofmann. - Chirurg. 2016. - No. 6. - P. 467-468.

4. Kluge J. Acute and chronic mediastinitis / J. Kluge // Chirurg. - 2016. - No. 6. - P. 469-477.

5. Surgical treatment of acute mediastinitis / M. Krüger, S. Decker, J. P. Schneider [et al.] // Chirurg. - 2016. - No. 6. P. 478-485.

6. Descending necrotizing mediastinitis / T. G. Elsahy, H. A. Alotair, A. H. Alzeer, S. A. Al-Nassar // Saudi Med. J. - 2014. No. 9. - P. 1123-1126

7. Hsin M. K. Video assisted thoracoscopic surgery is a valuable approach for the management of descending necrotizing mediastinitis / M. K. Hsin, A. P. Yim // Ann. Surg. - 2011. No. 5. - P. 1055-1056

8. Descending necrotizing mediastinitis: a modified algorithmic approach to define a new standard of care / J. D'Cunha, M. James, C. A. Green, R. S. Andrade // Surg. Infect.- 2013. - No. 6. P. 525-531.

9. Clinical features of deep neck infections and predisposing factors for mediastinal extension / S. K. Kang, S. Lee, H. K. Oh [et al.] // Korean J. Thorac. Cardiovasc. Surg. - 2012. - No. 3. - P. 171-176.

10. Surgical management of descending necrotizing mediastinitis / C. I. Lara Bayarri, S. López Sevilla, A. Ramos Sánchez-Palencia [et al.] // Cir. Esp. - 2013. - No. 9. - P. 579-583.

11. Optimal surgical options for descending necrotizing mediastinitis of the anterior mediastinum / X. Guan, W. J. Zhang, X. Liang [et al.] // Cell Biochem. Biophys. - 2014. - No. 1. - P. 109-114

\section{REFERENCES}

1. Аbакumov, M.M., Pogodina, A.N., \& Barmina, T.G. (2001). Dvadtsatiletniy opit diagnostiki i lecheniya pri raznikh formakh gnoynogo mediastinita [20 years of expiriense of diagnostic and treatment of different forms of purulent mediastinitis]. Vestnik khirurgii - News of Surgery, 1, 80-85 [in Russian].

2. Shipulin, P.P. (2001). Lecheniye ostrogo gnoynogo mediastinita [Treatment of acute purulent mediastinitis]. Khirurgiya - Surgery, 8, 58-61 [in Russian].

3. Hofmann, H.S. (2016). Mediastinitis. Chirurg., 87 (6), 467468. doi: 10.1007/s00104-016-0204-3.

4. Kluge, J. (2016). Acute and chronic mediastinitis. Chirurg., 87 (6), 469-477. doi: 10.1007/s00104-016-0172-7.

5. Krüger, M., Decker, S. Schneider, Haverich, A., Schega, O. (2016). Surgical treatment of acute mediastinitis. Chirurg., 87 (6), 478-485. doi: 10.1007/s00104-016-0171-8.

6. Elsahy, T.G., Alotair, H.A., Alzeer, A.H., \& Al-Nassar, S.A. (2014). Descending necrotizing mediastinitis. Saudi Med. J., 35 (9), 1123-1126.

7. Hsin, M.K., \& Yim, A.P. (2011). Video assisted thoracoscopic surgery is a valuable approach for the management of descending necrotizing mediastinitis. Ann. Surg., 253 (5), 1055-1056.

8. D’Cunha, J., James, M., Antonoff, M.B., Green, CA., Andrade, RS., et.al. (2013). Descending necrotizing mediastinitis: a modified algorithmic approach to define a new standard of care. Surg. Infect. (Larchmt), 14 (6), 525-531

9. Kang, S.K., Lee, S., Oh, H.K., Kang, M.W., \& Na, M.H. (2012). Clinical features of deep neck infections and predisposing factors for mediastinal extension. Korean J. Thorac. Cardiovasc. Surg., 45 (3), 171-176.

10. Bayarri, Lara C.I., Sevilla, López S., \& Sánchez-Palencia Ramos A. (2013). Surgical management of descending necrotizing mediastinitis. Cir. Esp., 91 (9), 579-583. doi: 1016/j. ciresp.2012.11.012.

11. Guan, X., Zhang, W.J., Liang, X., Liang, X., Wang, F., Guo et.al. (2014) Optimal surgical options for descending necrotizing mediastinitis of the anterior mediastinum. Cell Biochem. Biophys., 70 (1), 109-114.

Отримано 08.01.2019

\section{S. S. SNIZHKO}

Ivano-Frankivsk National Medical University

\section{SURGICAL TREATMENT OF THE UPPER DESCENDING PURULENT MEDIASTINITIS}

The aim of the work: to improve the results of treatment of patients with descending purulent mediastinitis by improving surgical access to mediastinum, and methods of local surgical treatment.

Materials and Methods. We performed a survey and treatment of 170 patients with low neck phlegmons (NP) that were treated at the Department of Thoracic Surgery in Ivano-Frankivsk Regional Clinical Hospital from 2000 to 2018 years. Among these patients, $53(31.2 \%)$ of the NP were complicated by development of descending purulent mediastinitis. Among 53 patients there were 34 men (64.2\%), women - 19 (35.8\%), 21-72 years of age, and the average age of patients was (41.3 \pm 3.9$)$ years.

Results and Discussion. Surgical treatment of descending purulent mediastinitis involves eliminating the primary source of the disease, choosing the surgical access to the mediastinum, disclosing all the purulent abscess and their sanation, ensuring the continuous 


\section{З ДОСВІДУ РОБОТИ}

removal of purulent masses from the mediastinum. To prevent the spread of NP in the mediastinum, we used the original method of intramediastinal administration of antibacterial drugs (IMAA). With the use of IMAA, we managed to reduce the incidence of DPM from $50.7 \%$ to $9.1 \%$ of cases. In 10 (20.8 \%) patients we conducted additional disclosure of mediastinal pleura of the upper mediastinum using video-assisted thoracoscopy (VATS). The use of VATS in the surgical treatment of DPM allows a complete review of the mediastinal pleura and mediastinum, allowing the effective surgery and rehabilitation of all affected mediastinal areas and their adequate drainage. With the use of surgical interventions to prevent the spread of purulent process in the mediastinum, we managed to reduce the number of repeated surgical interventions from $45.3 \%$ to $3.7 \%$.

Key words: mediastinitis; descending purulent mediastinitis; surgical treatment of purulent mediastinitis.

\section{с. С. СНИЖКО}

ГВУз “Ивано-Франковский национальный медицинский университет”

\section{ХИРУРГИЧЕСКОЕ ЛЕЧЕНИЕ ВЕРХНИХ НИСХОДЯЩИХ ГНОЙНЫХ МЕДИАСТИНИТОВ}

Цель работы: улучшить результаты лечения больных с нисходящим гнойным медиастинитом (НГМ) путем усовершенствования хирургических доступов к средостению, методов местного хирургического лечения.

Материалы и методы. Проведено обследование и лечение 170 больных с низкими флегмонами шеи (ФШ), которые находились на лечении в отделении торакальной хирургии Ивано-Франковской областной клинической больницы с 2000 по 2018 годы. Среди этих больных у 53 (31,2 \%) ФШ осложнилась развитием НГМ. Среди 53 больных мужчин было 34 (64,2 \%), женщин - 19 (35,8 \%), в возрасте от 21 до 72 лет, в среднем возраст больных составил $(41,3 \pm 3,9)$ лет.

Результаты исследований и их обсуждение. Хирургическое лечение НГМ предусматривает устранение первичного источника заболевания, выбор операционного доступа к средостению, раскрытие всех гнойных участков и их санацию, обеспечение постоянного удаления гнойных масс с клетчатки средостения. Для предупреждения распространения ФШ в клетчатку средостения мы применили оригинальную методику интрамедиастинального введения антибактериальных препаратов (ИМВА). При применении ИМВА нам удалось снизить частоту развития НГМ с 50,7 до 9,1% случаев. В 10 (20,8 \%) больных мы провели дополнительное раскрытие медиастинальной плевры верхнего средостения с помощью видеоасистированной торакоскопии (ВАТС). Использование ВАТС в хирургическом лечении НГМ позволяет провести полноценный обзор медиастинальной плевры и средостения, позволяет эффективно раскрыть и санировать все пораженные участки средостения и провести их адекватное дренирование. При применении хирургических вмешательств на опережение распространения гнойного процесса в средостении нам удалось снизить количество повторных оперативных вмешательств с 45,3 до 3,7 \%.

Ключевые слова: медиастинит; нисходящий гнойный медиастинит; хирургическое лечение гнойного медиастинита. 